\title{
Recent Western Historiography of the Time of Troubles in Russia
}

\author{
M. Perrie
}

For citation: Perrie M. Recent Western Historiography of the Time of Troubles in Russia. Vestnik of Saint Petersburg University. History, 2018, vol. 63, issue 1, pp. 244-261. https://doi.org/10.21638/11701/ spbu02.2018.116

This article reviews some English- and French-language works about the Time of Troubles which have been published since the Second World War. The author notes that there are relatively few such publications, and that there are no distinct Western "schools" of scholarship on the Time of Troubles. Rather, a number of individuals have written about aspects of the Troubles which interested them for a variety of reasons. The theme of pretenders has been a popular one. Philip Barbour wrote a biography of the First False Dmitrii; while Yves-Marie Bercé and Maureen Perrie have written about the phenomenon of pretendership, and the popular attitudes associated with it, from a comparative perspective. Other scholars (Roland Mousnier, Chester Dunning) have approached the popular uprisings of the Time of Troubles as responses to a "general crisis of the $17^{\text {th }}$ century". Yet others took as their starting points parallels with more recent times. Paul Avrich presented the Bolotnikov revolt as the first of a series of "peasant wars" that continued into the $20^{\text {th }}$ century; and Isaiah Gruber, in his monograph about the role of the Orthodox Church in the early $17^{\text {th }}$ century, identified similarities between the Time of Troubles and Russia's postSoviet ills. Many of these historians were influenced in their approaches by current tendencies in Western historiography and scholarship: comparative history; peasant studies; the history of revolts and revolutions; the semiotics of cultural history; and the history of mentalités.

Keywords: historiography, Time of Troubles, First False Dmitrii, pretenders, general crisis of the $17^{\text {th }}$ century, peasant wars, comparative history, peasant studies, revolts and revolutions, semiotics, mentalities, Russian Orthodox Church.

\section{Современная западная историография о Смутном времени в России}

\section{М. Перри}

Для цитирования: Perrie M. Recent Western Historiography of the Time of Troubles in Russia // Вестник Санкт-Петербургского университета. История. 2018. Т. 63. Вып. 1. С. 244-261. https:// doi.org/10.21638/11701/spbu02.2018.116

В статье рассматриваются некоторые работы о Смутном времени, публиковавшиеся на английском и французском языках с конца Второй мировой войны и до настоящего времени. Автор замечает, что таких публикаций вообще сравнительно мало и что нет

Perrie Maureen - M.A., Emeritus Professor, Centre for Russian, European and Eurasian Studies (CREES), Muirhead Tower, University of Birmingham, Edgbaston, Birmingham, B15 2TT, UK; m.p.perrie@bham.ac.uk

Перри Морин - М.А., проф., Центр по изучению России, Европы и Евразии, Бирмингемский университет, Бирмингем, В15 2TT, Великобритания; m.p.perrie@bham.ac.uk

(c) Санкт-Петербургский государственный университет, 2018 
особых западных «школ» историографии о Смуте. Скорее, некоторые отдельные ученые писали о тех аспектах Смутного времени, которыми интересовались по той или иной причине. Тема самозванчества привлекала немало внимания. Филип Барбер писал биографию первого Лжедмитрия, а Ив-Мари Берсэ и Морин Перри размышляли о феномене самозванчества и народных умонастроениях, связанных с ним, в сравнительной перспективе. Другие ученые (Ролан Мунье, Честер Даннинг) видели в народных восстаниях Смутного времени отклик на «общий кризис XVII века». Отправной точкой для иных историков являлась возможность проведения параллелей с событиями более новых времен. Пол Аврич изображал восстание Болотникова как первую войну в серии «крестьянских войн», продолжающейся до XX в., а Исаия Грубер в монографии о роли Русской православной церкви в начале XVII в. видел сходство между событиями Смутного времени и бедами постсоветской России. На подходы многих из этих историков воздействовали текущие тенденции в западной историографии и науке: сравнительная история; крестьяноведение; история восстаний и революций; семиотика культурной истории; история менталитетов.

Ключевые слова: историография, Смутное время, первый Лжедмитрий, самозванцы, общий кризис XVII века, крестьянские войны, сравнительная история, крестьяноведение, восстания и революции, семиотика, менталитет, Русская православная церковь.

Until the 1990s the only English-language books on early $17^{\text {th }}$ century Russia to include the words, the "Time of Troubles", in their titles were translations from Russian". There were however a few works with different titles which dealt with aspects of the period: a biography of the First False Dmitrii ${ }^{2}$; and a handful of volumes in English and French on popular revolts and mentalities ${ }^{3}$. This essay will review the works by Barbour, Mousnier, Avrich and Bercé, together with three books published more recently which use the term, "Time of Troubles", in their subtitles".

${ }^{1}$ Platonov S. F. The Time of Troubles: a Historical Study of the Internal Crisis and Social Struggle in Sixteenth- and Seventeenth-Century Muscovy. Lawrence, 1970 (is a translation of: Platonov S. F. Smutnoe vremia: ocherk istorii vnutrennego krizisa i obshchestvennoi bor'by v Moskovskom gosudarstve XVI i XVII vekov. Peterburg, 1923); Skrynnikov R. G. The Time of Troubles. Russia in Crisis, 1604-1618. Gulf Breeze (FL), 1988 (is a version of: Skrynnikov R. G. Minin i Pozharskii: khronika smutnogo vremeni. Moscow, 1981); Soloviev S. M.: 1) The Time of Troubles. Boris Godunov and False Dmitry. Gulf Breeze (FL), 1988 (Ser. History of Russia, vol. 14) (is a translation of: Solov'ev S. M. Istoriia Rossii s drevneishikh vremen. Moscow, 1960. Kniga IV (t. 7-8). P. 345-458); 2) The Time of Troubles. Tsar Vasily Shuisky and the Interregnum, 1606-1613. Gulf Breeze (FL), 1989 (Ser. History of Russia, vol. 15) (is a translation of: Solov'ev S. M. Istoriia Rossii s drevneishikh vremen. Moscow, 1960. Kniga IV (t. 7-8). P. 459-690).

There are also English translations of the popular biographies of Boris Godunov by Platonov and Skrynnikov: Platonov S. F. Boris Godunov, Tsar of Russia. Gulf Breeze (FL), 1973 (is a translation of: Platonov S. F. Boris Godunov. Petrograd, 1921); Skrynnikov R. G. Boris Godunov. Gulf Breeze (FL), 1982 (is a translation of: Skrynnikov R. G. Boris Godunov. Moscow, 1978).

2 Barbour P. L. Dimitry, Called the Pretender. Tsar and Great Prince of All Russia, 1605-1606. London, 1967.

3 Especially: Mousnier R. Peasant Uprisings in Seventeenth-Century France, Russia and China. London, 1971; Avrich P. Russian Rebels, 1600-1800. London, 1973; Bercé Y.-M. Le roi caché. Sauveurs et imposteurs. Mythes politiques populaires dans l'Europe moderne. Paris, 1990.

4 Perrie M. Pretenders and Popular Monarchism in Early Modern Russia: the False Tsars of the Time of Troubles. Cambridge, 1995; Dunning C. S. L. Russia’s First Civil War. The Time of Troubles and the Founding of the Romanov Dynasty. University Park PA, 2001; Gruber I. Orthodox Russia in Crisis: Church and Nation in the Time of Troubles. DeKalb (IL), 2012. 
Philip Barbour (1898-1980), the author of Dimitry, Called the Pretender, was a specialist on early colonial America. In 1953 he published a translation of Pushkin's Boris Godunov: in the Preface to his book on Dmitrii he explains that it was Musorgskii's opera, and especially Chaliapin's performance in the title role, that had led him to read Pushkin's play and subsequently to undertake his work on the pretender ${ }^{5}$. Barbour writes in an accessible manner, with a somewhat flowery literary style; the book is clearly intended for a general readership, but it is a much more scholarly piece of work than the average popular-historical biography ${ }^{6}$. Barbour was an excellent linguist ${ }^{7}$, and his book makes good use of printed primary sources in English, Russian, Polish, French, Italian, Latin, German, Swedish and Spanish, as well as a wide range of secondary authorities ${ }^{8}$. Barbour's extensive use of Polish sources, in particular, enables him to provide an unusually detailed picture of Dmitrii's contacts with his Polish and Jesuit entourage, both in the Rzeczpospolita and in Muscovy.

To the perennially intriguing question of the pretender's identity, Barbour offers no definitive answer. He is convinced, however, that Dmitrii was not a "deliberate impostor" or a "shabby fake", since all the evidence suggests that he confidently believed that he was the true heir to the throne ${ }^{9}$. In an Appendix, entitled, "Who was Dimitry?", the author revives the theory put forward by the journalist A.S. Suvorin, that Tsarevich Dmitrii did not die at Uglich in 1591, but was spirited away to safety by his kinsman Afanasii Nagoi and subsequently adopted by the Otrep'ev family under the name of Grigorii (Grishka). Thus the man who became Tsar Dmitrii in 1605 was indeed the renegade monk Grishka Otrepev, as generations of historians and chroniclers have claimed, but he was also the real Dmitrii, since the tsarevich had acquired the identity of Grishka after his escape from Uglich $^{10}$. Although he recognises that Suvorin's theory was a "somewhat fantastic tale"11, Barbour nonetheless argues that it deserves "serious consideration" and ought to be subjected to "modern historical analysis"12.

In line with his view that Dmitrii was a confident and self-assured claimant of the throne, Barbour presents him as a remarkable person, "one of history's truly extraordi-

${ }^{5}$ Barbour P.L. Dimitry, Called the Pretender. Tsar and Great Prince of All Russia...P.X.

${ }^{6}$ In that respect it is far superior to the popular biography of Boris Godunov by Ian Grey (1918-1996): Grey I. Boris Godunov: the Tragic Tsar. London, 1973. - An author who had previously written popular biographies of Peter the Great (1960), Catherine the Great (1961) and Ivan the Terrible (1964). Grey's book on Boris is mainly based on older Russian secondary sources such as the works of Karamzin, Solov'ev and Platonov. The author notes that Boris is best known in the West from Musorgskii's opera, which was largely based on Karamzin's History (Ibid. P. 14). Grey seeks to rehabilitate Boris from the accusations that Karamzin and others levelled against him: he absolves him of responsibility for the death of Tsarevich Dmitrii of Uglich, and presents him as a humane and enlightened ruler.

7 He had mastered native American languages for his work on colonial America.

8 Barbour worked in archives, including the Secret Archive of the Vatican, but his only new discovery was a previously unknown portrait of Dmitrii in the Hessische Landes- und Hochschulbibliothek, Darmstadt, which he reproduced as the frontispiece to his book.

9 Barbour P.L.Dimitry, Called the Pretender. Tsar and Great Prince of All Russia... P.XI, 321.

${ }_{10}$ Ibid. P. 321-327; Suvorin A.S. O Dimitrii Samozvantse. Kriticheskie ocherki. St Petersburg, 1906. P. 73-114.

11 Barbour P.L. Dimitry, Called the Pretender. Tsar and Great Prince of All Russia... P. 324.

12 Ibid. P. 327. - Suvorin's hypothesis about the rescue of Tsarevich Dmitrii is based largely on Jerome Horsey's account of his strange encounter with Afanasii Nagoi in Iaroslavl' one night in May 1591. For a re-examination of Horsey's evidence which makes this theory even more improbable, see: Perrie M. Jerome Horsey's Account of the Events of May 1591 // Oxford Slavonic Papers. 1980. New Series. Vol. XIII. P. 36-40, 44. 
nary figures"13. After coming to the throne on the crest of a wave of popular support, Dmitrii embarked on a programme of progressive reforms which in many ways - the author suggests - foreshadowed those of Peter the Great ${ }^{14}$. Muscovy at the beginning of the $17^{\text {th }}$ century, in Barbour's assessment, was still burdened by the traditional formality of a Byzantine court whose rigid procedures had been introduced into Russia by Ivan III, under the influence of his second wife Zoe (Sophia) Palaeologue ${ }^{15}$. The author draws a sharp contrast between Muscovite "backwardness" and "superstition" and the enlightened ideas of the "revolutionary young Tsar"16. But, Barbour argues, by failing to conceal his distaste for Muscovite tradition, Dmitrii revealed his rash and thoughtless character, and this was to prove to be his undoing, since it played into the hands of the reactionary boyar Prince Vasilii Shuiskii. Dmitrii's reliance on his Polish courtiers in his efforts to modernise Muscovy provided Shuiskii with a pretext for staging his coup against the tsar. The pretender's supporters, however, rose up under Bolotnikov in Dmitrii's name against Shuiskii and the "old regime" of "oppression of peasants and serfs" that Dmitrii had begun to ameliorate, in the "first and possibly the strongest and longest-lived revolution against Tsarist tyranny in the history of Russia before 1917"17. In general, Barbour pays little attention to the role of the masses in the Time of Troubles, but he does occasionally employ the terminology and concepts of Soviet historiography: he describes Khlopko's revolt of 1603 as "the first stage of the peasant war against the State" in which "the peasants and serfs had stepped over the brink of revolution"18; and in explaining popular support for Dmitrii he quotes with approval (from I. I.Smirnov's monograph on Bolotnikov ${ }^{19}$ ), Stalin's famous comment to Emil Ludwig about the people longing for a "good Tsar"20.

Another - and very different - work, which appeared at around the same time as Barbour's biography of Dmitrii, was much more concerned with the role of the peasantry. Roland Mousnier's book, which compares $17^{\text {th }}$ century peasant revolts in France, Russia and China, was first published in French ${ }^{21}$, and then in English translation in a series on "Great Revolutions"22. It brought together three types of scholarship that were very fashionable at that time: comparative history; peasant studies; and the study of revolutions and revolts. An interest in peasants, who had previously been of concern primarily to historians of medieval and early modern Europe, expanded after the Second World War, when the Chinese Revolution demonstrated that Russia's was not the only so-called socialist revolution to succeed in a country where the majority of the population were peasants, rather than industrial proletarians, as Karl Marx had predicted in the $19^{\text {th }}$ century. The wave of anti-colonial movements in Africa and Asia also raised both scholarly and popular inter-

13 Barbour P. L. Dimitry, Called the Pretender. Tsar and Great Prince of All Russia... P.XII.

14 Ibid. P. 104, 160, 162, 203.

15 Ibid. P.XI, 158, 233, 246.

16 Ibid. P. 104, 193, 209.

17 Ibid. P. 208-209, 274, 291-292, 356.

18 Ibid. P. 62-3.

19 Smirnov I. I. Vosstanie Bolotnikova 1606-1607. Leningrad, 1951. P. 28.

20 Barbour P.L. Dimitry, Called the Pretender. Tsar and Great Prince of All Russia... P.97, 116, 184, 291, 345.

${ }^{21}$ Mousnier R. Fureurs paysannes: Les paysans dans les révoltes du XVIIe siècle (France, Russie, Chine). Paris, 1967.

22 Mousnier R. Peasant Uprisings in Seventeenth-Century France, Russia and China. London, 1971. 
est in peasantries and their involvement in revolutionary events ${ }^{23}$. The role of the peasants in the Vietnam War led the radical American anthropologist Eric Wolf (1923-1999) to publish a book on six $20^{\text {th }}$ century cases of rebellion and revolution - Mexico, Russia, China, Vietnam, Algeria and Cuba - in which peasants were the principal actors ${ }^{24}$. This interest in the "peasant wars of the $20^{\text {th }}$ century", in its turn, revived interest in their earlier predecessors. Mousnier's choice of Russia and China as comparators to France for his $17^{\text {th }}$ century study may well have been influenced by contemporary scholarly interest in the Russian and Chinese revolutions of the $20^{\text {th }}$ century.

Roland Mousnier (1907-1993) was a distinguished historian of $17^{\text {th }}$ century France, and a fierce anti-Marxist ${ }^{25}$. He had participated in a famous debate in the left-wing English historical journal Past and Present on "The general crisis of the seventeenth century", which was launched by an article by the Oxford historian Hugh Trevor-Roper that compared the revolutions in England, France and Holland, in particular. Trevor-Roper rejected the Marxist view that these were "bourgeois revolutions" ${ }^{26}$, and concluded that they all resulted from a common crisis situation in which the social estates rebelled against their royal courts and the heavy burden of taxation they imposed ${ }^{27}$. Mousnier's book may be seen partly as an attempt to examine whether the generalisations which Trevor-Roper and others had made in relation to Western Europe could be extended to Eurasia more broadly ${ }^{28}$. In the Introduction to Peasant Uprisings he noted that there were revolts in the $17^{\text {th }}$ century across the world from England to Japan, as well as in Mexico; and he called for "a collective enterprise by historians of all countries to investigate the characteristics of such movements, in accordance with the different types of social structure involved, and the reasons for their coincidence in time" 29 .

Mousnier's book did not, of course, attempt to cover the entire world: he limited himself to three countries which, he said, he had chosen "because their social structures are very different" ${ }^{30}$. For France, he focussed on the Croquants of 1636-1637, the Nu-pieds of Normandy of 1639, and the Torrébens of Brittany of 1675. For Russia, he dealt with "The peasant revolts of the "Time of Troubles"' associated with the the False Dmitriis and Bolot-

23 The London-based Journal of Peasant Studies, which brought together the study of historical and contemporary peasantries in an inter-disciplinary approach, was founded in 1973.

${ }^{24}$ Wolf E. R. Peasant Wars of the Twentieth Century. New York, 1969.

${ }^{25}$ He was a harsh critic of the Soviet historian Boris Porshnev, whose book on popular uprisings in $17^{\text {th }}$-century France presented them as the result of a class struggle between the exploited and the exploiters.

26 Trevor-Roper's article was in part a response to a pair of articles by the English Marxist historian Eric Hobsbawm that had been published in Past and Present in 1954. See: Hobsbawm E. J.: 1) The General Crisis of the European Economy in the $17^{\text {th }}$ Century // Past and Present.1954a. N 5, May. P. 33-53; 2) The Crisis of the $17^{\text {th }}$ Century - II // Past and Present. 1954b. N 6, November. P. 44-65.

27 Trevor-Roper H. R. The General Crisis of the $17^{\text {th }}$ Century // Past and Present. 1959. N 16, November. P.31-64. See also the discussion by Mousnier and others in a subsequent issue of the journal, and Trevor-Roper's response - Discussion of H. R. Trevor-Roper: "The General Crisis of the $17^{\text {th }}$ Century" // Past and Present. 1960. N 18, November. P. 8-42. The debate was reprinted in: Crisis in Europe 1560-1660. Essays from "Past and Present". London, 1965.

28 The debate in Past and Present had not included discussion of Eastern Europe: when Hobsbawm criticised Trevor-Roper for failing to mention "the important Ukrainian upheaval" (the Khmel'nitskii revolt), Trevor-Roper replied that he doubted "whether general conditions in Eastern Europe were sufficiently similar to justify comparison"-Discussion of H. R. Trevor-Roper: "The General Crisis of the $17^{\text {th }}$ Century". P. $12,41$.

${ }_{29}$ Mousnier R. Peasant Uprisings in Seventeenth-Century France, Russia and China. London, 1971. P.XVIII-XIX.

${ }^{30}$ Ibid. P.XIX. 
nikov; and also with the revolt of Sten'ka Razin. For China, he investigated peasant revolts under the last Ming emperors. His study proceeded in a very systematic manner. For each country, he began with a chapter on its "social structures" (for Russia, there were separate chapters on the social structures of the late $16^{\text {th }}$ century and those on the eve of the Razin revolt). Then he provided a narrative account of each revolt, before a lengthy Conclusion in which he compared the three sets of revolts in terms of conjunctures or circumstances (short-term causes) on the one hand, and social structures (deeper long-term factors) on the other.

As a specialist on $17^{\text {th }}$ century France, Mousnier devoted the largest proportion of his text to the French revolts. His source base for these was much richer than for the Russian and Chinese events; he cites a wide range of primary materials, including archives. For Russia, his discussion of the social structures provided references only to general histories in English and French, including some translations from Russian (Miliukov, Kliuchevskii, Liashchenko). The only primary sources he cites for his chapter on the Time of Troubles are from the collection of documents on the Bolotnikov revolt compiled by A. I. Kopanev and A. G. Man'kov ${ }^{31}$. His chapters on China seem to rely exclusively on secondary sources in English and French. In general, Mousnier's discussion of the Chinese revolts is quite brief and superficial, and the main interest of his book is the comparison between Russia and France. The author's main argument about $17^{\text {th }}$ century France is that it was not a class society, but a highly stratified society of orders or estates, and that the main social divisions in the revolts were not horizontal, but vertical. Russian society on the eve of the Time of Troubles, by contrast, was much less differentiated, and although attempts were made by the tsars to create a society of orders, based on service to the state, Russia remained more like a class society, with polarisation between landholders and peasants ${ }^{32}$.

Mousnier's argument about the significance of social structures in influencing the nature of the revolts in each country becomes somewhat clearer in his extended Conclusion. He begins by examining common causes for the revolts in the three countries, and concludes that these were: an increased burden of taxation in order to pay for armies; economic problems that particularly affected the peasants; and climatic variations leading to bad harvests and epidemics. All of these conjunctures or circumstances, he suggests, may even be sufficient in themselves to explain the revolts ${ }^{33}$. Nevertheless, he raises a number of questions about the revolts, which leads him to discuss whether they display any "differences that can be explained by differences in social structure" ${ }^{34}$. First of all, he asks who began the revolts and whether their initiators acted spontaneously. His answer is that the peasants did not take the initiative in any of the three countries ${ }^{35}$. In the Russian case, he acknowledges that "in the years preceding the Time of Troubles" (i.e. in the Khlopko uprising of 1603), "it was the peasants, apparently, who began the movements". The author recognises that the majority of the participants in Khlopko's movement were bandits, but he argues that "most of the bandits were of peasant origin", although he ad-

31 Vosstanie I. Bolotnikova. Dokumenty i materialy. Moscow, 1959. - It is not clear whether Mousnier read Russian himself, or relied on research assistance.

${ }^{32}$ Mousnier R. Peasant Uprisings in $17^{\text {th }}$ France, Russia and China. London, 1971. P. 153-178.

33 Ibid. P.306-319.

34 Ibid. P.XX.

35 Ibid. P. 327. 
mits that historians here face a problem "that always arises when people change their social position - should they be classified according to their origin or according to their new social function?" 36 . The Time of Troubles proper, however (which Mousnier dates from the appearance of the First False Dmitrii in Poland), was begun by the boyars who plotted against Boris Godunov; Dmitrii's first supporters were cossacks, along with runaway peasants and vagabonds; and peasants themselves did not participate until the "true tsar" appeared in Russia ${ }^{37}$.

Mousnier's second question concerns the motives or grievances of the rebels. Here he concludes that in all three countries it was the action of the state, rather than social antagonisms, that motivated the revolts ${ }^{38}$. In the Time of Troubles, the main grievance for all participants was the perceived illegitimacy of Boris Godunov's claim to the throne; the specific motives of the peasants were the burden of taxation and the process of enserfment by the state ${ }^{39}$. The third question relates to the geographical area covered by the revolts, where the author suggests that distance from the capital was a common feature ${ }^{40}$ (although for Russia this was more relevant to the Razin revolt than to the Time of Troubles). In relation to his next question, concerning the organisation and outcome of the revolts, Mousnier concludes that in Russia, as elsewhere, there was no distinct peasant organisation. In the Time of Troubles the peasants were led by boyars and pomeshchiki; during the Bolotnikov revolt, the rebels elected their own voevody, but it is not clear whether any peasants participated in this ${ }^{41}$. Finally, Mousnier considers the programme or aims of the rebels. In France, he argues, the rebels simply wanted to return to an idealised version of the past, and the same was true of the Russian peasants in the Time of Troubles, although he suggests that Bolotnikov may have wanted rather more: a remodelling of the Russian state and society on the basis of equal redistribution of the land and popular election of leaders, under a "good tsar"42. Mousnier acknowledges that the sources leave room for doubt about how far Bolotnikov was proposing a "real peasant revolution", but he believes that Razin did indeed envisage such a revolution ${ }^{43}$.

So at last Mousnier reaches the climax of his investigation into the relevance of social structures to differences in the character of peasant revolts. Why were Russian revolts revolutionary (or at least quasi-revolutionary) while French (and Chinese) ones were not? One answer was that French peasants (like those of China) enjoyed property rights and personal liberties within the social system, where Russian peasants were increasingly losing these, with the advance of serfdom. Another factor was the openness of French society, with its social mobility and high degree of social stratification, while Russian society was closed and immobile, especially after 1649. It was the dichotomy or polarisation of Rus-

${ }^{36}$ Ibid. P. 326, cf. pp. 180-181. - This is of course one of the issues which divided Soviet supporters of the "peasant war" approach to the Time of Troubles from their critics: whether the term "peasants" refers solely to agriculturists, or to all those of peasant origin or background (including cossacks, bandits, strel'tsy and others) who participated in the revolts.

37 Ibid. P. 326, cf. pp. 181-184.

38 Ibid. P. 332.

39 Ibid. P. 330-331.

40 Ibid. P. 332-337.

${ }^{41}$ Ibid. P. 340, cf. pp. 187.

42 Ibid. P. 341-344.

${ }^{43}$ Ibid. P. 187, 344. 
sian society, Mousnier argues, that created hopes of revolution among the peasants and slaves, who saw no other way of improving their position ${ }^{44}$.

Mousnier's book does of course have many weaknesses from the point of view of a historian of Russia. His sources are limited, and much of the secondary literature he consulted was outdated even at the time he was writing, in the 1960s. But, as a serious professional historian, he himself is fully aware of these limitations ${ }^{45}$, and he deserves to be commended for his bravery in venturing into such unfamiliar territory. He asks interesting questions, and proposes suggestive answers. And he is not embarrassed to have reached conclusions about the revolutionary nature of the Russian revolts that are very similar to the conclusions of Soviet historians, especially since he was so critical of Porshnev's Marxist interpretation of the uprisings in France.

Another scholar who was venturing into unfamiliar territory when he wrote about the Time of Troubles was the American historian Paul Avrich (1931-2006), whose previous publications had been on Russian anarchism in the $19^{\text {th }}$ and $20^{\text {th }}$ centuries. Avrich's book deals with the four popular revolts that were identified in Soviet historiography as "peasant wars": those led by Bolotnikov, Razin, Bulavin and Pugachev. He devotes a chapter to each of these rebellions, and in his concluding chapter he compares these earlier revolts to the revolutions of 1905 and 1917. In spite of the obvious differences between them, Avrich sees some striking similarities between the $20^{\text {th }}$ century revolutions and their earlier predecessors: all were complex spontaneous explosions of mass discontent, directed against the state as well as against the rich and the powerful. But he argues that there were also continuities between the earlier revolts and the popular rebellions against the new Bolshevik regime during the Russian Civil War: those led by Makhno and Antonov, and the Kronstadt sailors' uprising ${ }^{46}$.

Unlike some other Western historians, Avrich is happy to use the term "peasant wars" to describe the four popular revolts of the early modern period ${ }^{47}$. He recognises that Soviet historians borrowed the term from Friedrich Engels' study of $16^{\text {th }}$ century Germany, partly in order to draw an analogy between the course of Russian history and that of western and central Europe. Avrich acknowledges that the social and ethnic composition of the participants in all four "peasant wars" was complex, with cossacks playing an important leadership role. Nevertheless, he claims that peasants were the most numerous recruits to the movements, "so that the label "peasant wars", however imprecise, does in fact convey something of the nature of the risings". Moreover, he notes (as had Roland Mousnier) that many of the other categories of participants, including the cossacks, "were themselves essentially peasants, only recently uprooted from the soil", and that the majority of the "tribal adherents" to the revolts (the Mordva, Mari and Chuvash) were settled agriculturists rather than nomads ${ }^{48}$. In the concept of the "peasant war" Avrich also sees an element of continuity between the early-modern revolts and the revolutions of 1905 and 1917. He notes that both Marx and Lenin had identified "peasant wars" as accompaniments of proletarian revolutions in the modern period, and that Zinov'ev and Trotsky

${ }^{44}$ Ibid. P. 344-348.

45 See, for example: Ibid. P. 325-326.

46 Avrich P. Russian Rebels, 1600-1800. P. 268-272.

47 For an early critique of Soviet historiography on the "peasant wars", see: Yaresh L. The "Peasant Wars" in Soviet Historiography // American Slavic and East European Review. 1957. Vol. 16, N 3, October. P. 241-259.

${ }^{48}$ Avrich P. Russian Rebels, 1600-1800. P.4-5. 
had used the term in relation to the Russian revolution of 1917. These Marxist thinkers, Avrich argues, had borrowed their analysis from Bakunin, who had seen the Razin and Pugachev revolts as prototypes of a forthcoming Russian anarcho-socialist revolution of all the dispossessed elements in society. Such revolutions, incorporating "peasant wars", he notes, had occurred in the $20^{\text {th }}$ century not only in Russia, but also in China and in Spain ${ }^{49}$ (in Spain, of course, the anarchists played an important role on the Republican side in the Civil War) ${ }^{50}$.

Avrich's chapter on Bolotnikov in fact comprises quite a general narrative of the Time of Troubles, with brief background discussion of the reign of Ivan the Terrible. Khlopko is presented as the "first important social rebel" of the Time of Troubles, and the First False Dmitrii as a messiah-like figure whose followers opposed both autocracy and serfdom. Bolotnikov's supporters included relatively few peasants, but his revolt was "a social rebellion of the poor against the rich" ${ }^{\prime 2}$. Avrich makes use of a wide range of printed primary sources, including the collection of documents edited by Kopanev and Man'kov ${ }^{52}$, and of Russian-language secondary literature including Smirnov's monograph ${ }^{53}$. His interpretation of the role of the samozvantsy in the Bolotnikov revolt, and in the other revolts which he discusses, is heavily influenced by K.V.Chistov's concept of socio-utopian legends about "returning tsar-deliverers" 54 . The author's approach to the rebellions is not, however, solely derived from Soviet scholarship: in his Introduction, he refers to the model established by recent Western historians of popular movements such as Eric Hobsbawm and George Rudé5 ${ }^{5}$. Avrich's book is scholarly in character, with detailed endnotes and a selective bibliography, but it is written in a lively and accessible style, suitable for the general reader. It has been a popular item on student reading lists for university courses on early modern Russian history for many years.

One of the most interesting and original comparative studies to include discussion of the Time of Troubles is a book by the French historian Yves-Marie Bercé (b.1936) on "popular political myths" in modern Europe ${ }^{56}$. Bercé, like Roland Mousnier, was a specialist on French popular revolts in the $17^{\text {th }}$ century, and in 1980 he published a comparative study of revolts and revolutions in early modern Europe ${ }^{57}$. This book included relatively little discussion of Russian revolts, although there were two chapters on "peasant wars". In the first of these, devoted to the $16^{\text {th }}$ and $17^{\text {th }}$ centuries, a section on "The Cossack revolts", which depicted them as examples of resistance to the "second serfdom", included brief discussion of Bolotnikov and Razin, as well as the Khmel'nitskii rebellion

49 Ibid. P. 265-267.

${ }^{50}$ For the Russian and Chinese revolutions as "peasant wars of the $20^{\text {th }}$ century", see also: Wolf E. R. Peasant Wars of the Twentieth Century, mentioned above.

51 Avrich P. Russian Rebels, 1600-1800. P. 14, 15-16, 23, 25.

52 Vosstanie I. Bolotnikova. Dokumenty i materialy.

53 Smirnov I. I. Vosstanie Bolotnikova 1606-1607.

${ }^{54}$ Chistov K. V. Russkie narodnye sotsial'no-utopicheskie legendy XVII-XIX vv. Moscow, 1967. P. $24-$ 236.

55 Avrich P. Russian Rebels, 1600-1800. P.7; Hobsbawm E. J. : 1) Primitive Rebels. Studies in Archaic Forms of Social Movement in the $19^{\text {th }}$ and $20^{\text {th }}$ Centuries. Manchester, 1959; 2) Bandits. Harmondsworth, 1972; Rudé G. The Crowd in History. A Study of Popular Disturbances in France and England, 1739-1848. London, 1964.

${ }^{56}$ Bercé Y.-M. Le roi caché. Sauveurs et imposteurs. Mythes politiques populaires dans l'Europe moderne. Paris, 1990.

57 Bercé Y.-M. Révoltes et révolutions dans l'Europe moderne (XVIe - XVIIIe siècles). Paris, 1980. 
in Ukraine ${ }^{58}$. An earlier chapter, on the "guiding myths" of the revolts ${ }^{59}$, included some discussion of the ideas that were to be developed much more fully in Le roi caché (The hidden king).

Le roi caché takes as its starting point the virtually simultaneous appearance, in the late $16^{\text {th }}$ and early $17^{\text {th }}$ centuries, of pretenders claiming to be Don Sebastian of Portugal, who had died at the battle of Alkazarquivir in 1578; the False Dmitriis of the Russian Time of Troubles; and a pretender calling himself François de Valois, a non-existent son of Charles IX of France ${ }^{60}$. Bercé suggests that the amount of popular support obtained by all of these pretenders indicates that their stories resonated with popular expectations concerning royal heroes. He identifies three types of such legendary figures: the sacrificial king; the royal guardian; and the well-informed monarch (le roi avisé). The first category includes the Emperor Charles V, who voluntarily abdicated in order to live a life of prayer in a secluded monastery; in the second category Bercé places monarchs such as Charlemagne and King Arthur, who were believed not to be dead, but only sleeping, in a mountainside cave or on a distant island, from whence they would come again to save their people in their hour of need. In the third category we find kings who are suspicious of the advice of evil counsellors, and who seek to learn about their subjects' needs and problems by travelling incognito through their kingdoms in order to discover the truth for themselves. The classic example of this stereotype is Haroun al-Rashid, the Caliph of Baghdad who supposedly wandered at night through his capital in disguise; European examples include Shakespeare's Henry V on the eve of the battle of Agincourt; and Samuel Collins, of course, recorded similar tales about Ivan the Terrible ${ }^{61}$.

Having devoted a chapter to each of these varieties of "hidden king", Bercé tries to explain the phenomenon of pretendership and the related phenomenon of support for pretenders. Pretenders gain popular support, he suggests, in "situations of expectation" - some kind of social, economic or political crisis. But such a crisis can only give rise to a pretender movement in an ideological or religious context that leads a people to cherish hopes for a better future ${ }^{62}$. The author then examines the psychology of the pretenders themselves. He acknowledges that some of them were criminal fraudsters, but suggests that others may have suffered from some kind of identity crisis, which in certain cases may have been created by the "situations of expectation" he has previously discussed $^{63}$. In his final chapter Bercé argues that the myths about hidden kings reveal popular concepts about monarchical legitimacy that differ from those of official political philosophy. These popular concepts include the idea of a charismatic dynasty, and

58 Bercé Y.-M. Revolt and Revolution in Early Modern Europe. An Essay on the History of Political Violence. Manchester, 1987. P. 159-163.

59 Ibid. P.3-33.

60 Bercés chapter on the Russian pretenders is based mainly on secondary sources and on accounts by foreign visitors that are available in English and French. He cites some works by Russian historians, but it is not clear how far he himself is familiar with the language: in his "Acknowledgments" he thanks his French colleague Vladimir Vodoff (1935-2009), a specialist on medieval Russian history, for his assistance with the chapter on the Time of Troubles - Bercé Y.-M. Le roi caché. Sauveurs et imposteurs. Mythes politiques populaires dans l'Europe moderne. P.9.

${ }^{61}$ Bercé Y.-M. Le roi caché. Sauveurs et imposteurs. Mythes politiques populaires dans l'Europe moderne. P. 305

62 Ibid. P. 312.

${ }^{63}$ Ibid. P. 340. 
the belief that true kings have special physical characteristics, or special powers to cure disease ${ }^{64}$.

Bercé's book is highly erudite, and it brings together a huge number of popular ideas about monarchy, with examples from a wide range of countries and historical periods. His argument that pretenders acquire popular support because their stories resonate with myths and legends about hidden kings is generally persuasive. It must be said, however, that many of the myths he discusses - for example, those from classical antiquity or medieval chivalric romances - were largely unknown in Russia before the Time of Troubles, and it is doubtful how far they could have influenced support for the False Dmitriis. Nevertheless, one of the author's most stimulating arguments is that the image of the returning king has much in common with the figure of the risen Christ, which was of course well known in all Christian countries, including Russia. Expectation of the return of the hidden king was a kind of messianism, Bercé suggests, but it was a secular messianism, since the king's return was not miraculous: "he was not resurrected, he simply returned"65.

Like Paul Avrich (see above), the British historian Maureen Perrie (b.1946) began her career by writing about the Russian revolutionary movement in the late $19^{\text {th }}$ and early $20^{\text {th }}$ centuries: in her case, about the Socialist-Revolutionary (SR) Party and the peasantry in the revolution of 1905. Her work on the SRs led Perrie to investigate the phenomenon of "popular monarchism" - peasant faith in the goodness and benevolence of the tsar - which had acted as an obstacle for the revolutionary socialists when they tried to conduct propaganda about a democratic republic. Perrie subsequently published a book on the image of Ivan the Terrible as a "good tsar" in Russian folklore, before writing about popular monarchism in relation to the Time of Troubles. In the Preface to her book, Perrie noted that she had originally been attracted to the topic by notions of pretenders as "social bandits", of their supporters as "primitive rebels", and of the Time of Troubles as a "peasant war" whose participants were guided by "socio-utopian legends about returning royal deliverers" 66 . After some preliminary research, however, she had concluded that the relevance of these ideas was not supported by the evidence, and her approach was instead influenced by semiotic interpretations and by the concept of mentalité $e^{67}$.

Perrie situates the Russian pretenders of the Time of Troubles in the broader context of other pretenders in early modern Europe - Lambert Simnel and Perkin Warbeck in $15^{\text {th }}$ century England; the Moldavian pretenders of the late $16^{\text {th }}$ century; and the false Don Sebastians of Portugal - and she notes some common features behind them, such

${ }^{64}$ For a discussion of the idea of "royal marks" in relation to Russian pretenders, see: Perrie M. "Royal Marks": Reading the Bodies of Russian Pretenders, $17^{\text {th }}-19^{\text {th }}$ Centuries // Kritika: Explorations in Russian and Eurasian History. 2010. New Series. Vol. 11, N 3, Summer. P. 535-561.

${ }^{65}$ Bercé Y.-M. Le roi caché. Sauveurs et imposteurs. Mythes politiques populaires dans l'Europe moderne. P. 228-229, 312-313.

${ }^{66}$ On the concept of pretenders as "social bandits", see: Hobsbawm E. J.Bandits. P.101 and Longworth P. The Pretender Phenomenon in Eighteenth-Century Russia // Past and Present. 1975. N 66, February. P.73-74. For the term "primitive rebels", see: Hobsbawm E. J.Primitive Rebels. Studies in Archaic Forms of Social Movement in the $19^{\text {th }}$ and $20^{\text {th }}$ centuries. For "socio-utopian legends about returning deliverers", see: Chistov K. V. Russkie narodnye sotsial'no-utopicheskie legendy XVII-XIX vv. Moscow, 1967. P. 24-236 and Perrie's critique of the concept in: Perrie M. "Popular Socio-Utopian Legends" in the Time of Troubles // Slavonic and East European Review. 1982. Vol.60, N 2, April. P. 221-243.

${ }^{67}$ Perrie M. Pretenders and Popular Monarchism in Early Modern Russia: the False Tsars of the Time of Troubles. Cambridge, 1995. P.X. 
as the existence of a dynastic crisis. Perrie accepts the conventional identification of the First False Dmitrii as Grisha Otrepev; she believes, however, that he was not the agent of boyars such as the Romanovs, but initially acted independently, before acquiring influential patrons in Poland-Lithuania. After his invasion of Russia, he gained support from all sections of society by claiming to be the "true tsar"; he may also have capitalised on the notion, fostered by the "sacralisation" of the monarchy in the $16^{\text {th }}$ century, that he had literally risen, Christ-like, from the grave ${ }^{68}$. Later in the Time of Troubles, however, lower-class rebels denounced Vasilii Shuiskii's supporters as traitors to the "true tsar" Dmitrii, thereby legitimising their attacks on the rich and privileged elements of society. Perrie suggests that the popular image of Dmitrii as a "good tsar", the champion of ordinary people against the "traitor-boyars", had much in common with the folkloric image of his supposed father, Ivan the Terrible ${ }^{69}$.

Perrie did not consult archival sources, but in her discussion of the cossack pretender-tsareviches on the Volga in 1606-1607 she made use of detailed accounts of a Carmelite mission to Persia which had not previously been used by Russian historians ${ }^{70}$. In general, Perrie devoted more attention to these cossack tsareviches than had most earlier historians; she noted that, unlike the False Dmitriis, "Tsareviches" Petr, Ivan Avgust, Fedor Fedorovich and others did not claim the throne for themselves, but claimed to be relatives of "Tsar Dmitrii" and acted in his name - sometimes, as in the case of Tsarevich Petr, against the "wicked boyars" who had prevented the tsar from rewarding them for their support ${ }^{71}$.

Perrie's book does not claim to be a general history of the Time of Troubles, although the author does present an account of the main events of the early $17^{\text {th }}$ century, in more or less chronological order, as background to the appearance and activity of the pretenders. A fuller narrative of the period was provided by Chester Dunning (b.1949), an American historian whose first major publication on the Time of Troubles was an annotated translation of the account of the period written by Captain Jacques Margeret, a French

68 Ibid. P. 65-69. - Thus Perrie presents support for Dmitrii as a genuinely religious form of messianism, unlike Yves-Marie Bercé, who saw expectation of the return of the hidden king as a form of secular messianism (see above). In a similar manner to Bercé, K. V. Chistov distinguished between "religious-messianic legends about 'saviours" and "legends of a socio-political character about 'returning tsar- or tsarevich-deliverers"': Chistov K. V. Russkie narodnye sotsial'no-utopicheskie legendy XVII-XIX vv. P. 24, 224-225, 338339. On the sacralisation of the monarchy, see: Uspenskii B. A. Tsar' i samozvanets: samozvanchestvo v Rossii kak kul'turno-istoricheskii fenomen // Khudozhestvennyi iazyk srednevekov'ia. Moscow, 1982. P. 201-235.

69 Perrie M. Pretenders and Popular Monarchism in Early Modern Russia... P. 248.

70 Ibid. P.131-134, 144-149. See: Berthold-Ignace de Sainte-Anne, Révérend Père // Histoire de l'Établissement de la Mission de Perse par les Pères Carmes-Déchaussées (de l'année1604 à 1612). Brussels, 1885; Florencio del Niño Jesús, P. Fr. A Persia (1604-1609). (Biblioteca Carmelitano-Teresiana de Misiones, t. II). Pamplona, 1929; Florencio del Niño Jesús, P. Fr. En Persia (1608-1624). (Biblioteca Carmelitano-Teresiana de Misiones, t. III). Pamplona, 1930.

${ }^{71}$ Perrie M. Pretenders and Popular Monarchism in Early Modern Russia... P. 247-248. - In later articles Perrie developed this analysis to include Sten'ka Razin's "Tsarevich" Aleksei Alekseevich and the Zaporozhian cossacks' "Tsarevich" Simeon Alekseevich of 1673-1674. She described these cossack tsareviches as "pretenders in the name of the tsar", who did not challenge the legitimacy of the reigning monarch, and she drew a distinction between these "intra-dynastic pretenders", on the one hand, and "inter-dynastic pretenders" such as the False Dmitriis, on the other: Perrie M. Pretenders in the Name of the Tsar: Cossack "Tsareviches" in Seventeenth-Century Russia // Von Moskau nach St. Petersburg. Das russische Reich im 17. Jahrhundert (Forschungen zur osteuropäischen Geschichte, vol. 56). Wiesbaden, 2000. S. 243-256; Perri [Perrie] M. Samozvantsy XVII v. i vopros o legitimnosti praviashchego tsaria // Samozvantsy i samozvanchestvo v Moskovii. Materialy mezhdunarodnogo nauchnogo seminara (25 maia 2009 g., Budapesht). Ed. by Diula Svak. Budapest, 2010. P. 66-88. 
mercenary soldier who had been in service both to Boris Godunov and to the First False Dmitrii ${ }^{72}$. In the Preface to his book on the Troubles, Dunning wrote that his original intention had been "to correct many glaringly obvious errors in Soviet scholarship", which had presented the period as a social revolution against serfdom. In the last few years, however, revisionist historians had abandoned this view in favour of the concept of a civil war "that split Russian society vertically instead of horizontally", and Dunning had decided instead to write a more general history of the Time of Troubles ${ }^{73}$.

Dunning's book is a substantial work of synthesis, drawing on the revisionist interpretations of both Russian and Western historians: he includes an impressive bibliography of published primary and secondary sources. The main body of the text is a detailed narrative of events from 1603 to 1610 (the concluding stages of the Troubles are covered much more briefly), with a strong focus on military issues. The introductory chapters provide background information. In the first chapter he offers a review of comparative history, beginning with the theory of a "general crisis" of the $17^{\text {th }}$ century (see above). Dunning is particularly impressed by a work by the American sociologist Jack Goldstone, who explains revolts and revolutions in early modern Eurasia in terms of population growth and price inflation ${ }^{74}$. Goldstone does not deal specifically with Russia; and Dunning recognises that data on demography and prices in late $16^{\text {th }}$ century Muscovy is problematic; nevertheless, he concludes that Goldstone's model applies to Russia and helps to explain the Time of Troubles ${ }^{75}$. Dunning's subsequent background chapters review Russian history in the $16^{\text {th }}$ century, in the hope of discovering there the long-term origins of the civil war. He concludes, however (as had many historians before him), that although the country was facing a number of crises at the beginning of the $17^{\text {th }}$ century, it was only the appearance of the First False Dmitrii in Poland-Lithuania, and his invasion of Russia in 1604, that triggered a civil war $^{76}$.

In spite of the length and detail of Dunning's background chapters, there are some curious omissions. His comparative material does not include any discussion of the many

72 Margeret J. The Russian Empire and Grand Duchy of Muscovy. A $17^{\text {th }}$ Century French Account. Pittsburgh, 1983.

73 Dunning C.S. L. Russia's First Civil War. The Time of Troubles and the Founding of the Romanov Dynasty. 2001. P.XI. - The revisionists included some Russian historians writing in the late Soviet period: Skrynnikov R. G. : 1) Rossiia v nachale XVII v. "Smuta". Moscow, 1988; 2) Smuta v Rossii v nachale XVII v. Ivan Bolotnikov. Leningrad, 1988; Stanislavskii A. L. Grazhdanskaia voina v Rossii XVII v. Kazachestvo na perelome istorii. Moscow, 1990; Skrynnikov R. G. The Civil War in Russia at the Beginning of the Seventeenth Century (1603-1607): its Character and Motive Forces // New Perspectives on Muscovite History. Selected Papers from the Fourth World Congress for Soviet and East European Studies, Harrogate, 1990. Houndmills, 1993. P.61-79. As well as: Perrie M. Pretenders and Popular Monarchism in Early Modern Russia... Dunning recognises that many Western scholars had used similar concepts to those of Soviet historians when writing about the Time of Troubles: Dunning C.S. L. Russia's First Civil War. The Time of Troubles and the Founding of the Romanov Dynasty. P. 3. He himself used the term "first peasant war" quite uncritically in his edition of Margeret: Margeret J. The Russian Empire and Grand Duchy of Muscovy. A $17^{\text {th }}$ Century French Account. Pittsburgh, 1983. P.XXX, 168, 169, 173, 176.

${ }_{74}$ Goldstone J. A. Revolution and Rebellion in the Early Modern World. London, 1991.

75 Dunning C.S.L. Russia's First Civil War. The Time of Troubles and the Founding of the Romanov Dynasty. P. 17-27. - Robert Crummey, the distinguished North American historian of early modern Russia, had however earlier concluded that the Muscovite evidence does not fit Goldstone's model, see: Crummey R. O. Muscovy and the "General Crisis of the Seventeenth Century"// Journal of Early Modern History. 1998. Vol. 2. P. 156-180.

76 Dunning C.S.L. Russia's First Civil War. The Time of Troubles and the Founding of the Romanov Dynasty. P. 109. 
pretenders in early modern Europe whose claims preceded those of the First False Dmitrii and may have served as a model for him: he makes no mention, for example, of the false Don Sebastians, who were seen by Dmitrii's contemporaries in Poland, and by Pope Clement VIII, as prototypes for the Russian pretender. Indeed, Dunning's narrative of $16^{\text {th }}$ century events deals almost entirely with domestic Russian developments, largely ignoring foreign affairs and the broader European context: he does not consider the Counter-Reformation and the Union of Brest that created the Uniate Church, nor does he explain events in Poland-Lithuania and on the Baltic. Because of these omissions, a non-specialist reader would find it difficult to understand the attitudes of the elites in the Rzeczpospolita and of the Catholic hierarchy towards the appearance of the pretender at Brahin.

The most striking feature of Dunning's book is the highly positive picture he presents of the First False Dmitrii. Dunning is not convinced by the evidence that the pretender was Grishka Otrepev, but he offers no alternative explanation of his identity, other than to suggest that he might actually have been the real Tsarevich Dmitrii of Uglich. Dunning (like Philip Barbour and others) believes that "Dmitrii" was not a conscious impostor, but was genuinely convinced that he was the tsarevich ${ }^{77}$. He was not the tool of the Jesuits or the Poles: his secret conversion to Catholicism was merely "a necessary political ploy" to obtain support in Poland, as was his promise of the concession of Russian territory to Jerzy Mniszech $^{78}$. When he came to the throne, Dmitrii proved to be no revolutionary: he may have behaved as an unconventional, Westernised ruler, but his policies were traditional ones, in line with those of his predecessors, including Boris Godunov ${ }^{79}$. Nevertheless, Dunning suggests, Dmitrii was an exceptional figure, whose "unique and remarkable story" set the precedent for all subsequent pretenders in Russian history ${ }^{80}$.

If many of the books we have considered so far place aspects of the Time of Troubles in the context of broader themes that concerned Western historians in the decades following the Second World War - such as comparative history, peasant studies, and the history of rebellions and revolutions - then a more recent work by a member of the younger generation of American historians derives from a different agenda. In the Preface to his book on the Orthodox Church during the Time of Troubles, Isaiah Gruber (b.1977) states that he became interested in the topic because of the resurgent role of religion in the post-Soviet period - Russias "new Time of Troubles" ${ }^{81}$; he draws attention to the revival of interest in the period in Russia itself, and to the creation in 2005 of the new public holiday of the "Day of National Unity" on 4 November, commemorating the liberation of Moscow in 1612 and the supposed role in the victory of the Kazan' icon of the Mother of God ${ }^{82}$.

Gruber deals with the history of the Church in the early $17^{\text {th }}$ century in more or less chronological order, but he identifies four main themes which he pursues throughout his narrative. The first of these is the representation of Russia as "New Israel". As the author recognises, Christians of virtually all denominations share the view that they have replaced the Jews as God's "chosen people", but Gruber argues that the New Israel idea

77 Ibid. P. 131-132.

78 Ibid. P. 135-136.

79 Ibid. P. 202-204.

80 Ibid. P. 119-122, 479 .

81 Gruber I. Orthodox Russia in Crisis: Church and Nation in the Time of Troubles. DeKalb (IL), 2012. P.IX.

82 Ibid. P. 11-12. 
acquired a distinctive form in Russia after the fall of Constantinople to the Turks in 1453, when Muscovy became the world's only independent Orthodox state, claiming to preserve the true Christian faith. The idea of Muscovy as the New Israel, Gruber suggests, was more influential in $16^{\text {th }}$ century Russia than the similar notion of Moscow as the Third Rome; and its significance developed further during the Time of Troubles, when Orthodox churchmen compared the sufferings of the Russian people to the afflictions of the Jews during their Babylonian captivity and Roman exile. While the concept of New Israel increased in prominence during the Troubles, the idea of the Third Rome declined: perhaps, the author suggests, because of Russians' identification of Rome with the Polish-Lithuanian Catholic invaders ${ }^{83}$.

Gruber's second theme - for which he made use of some archival materials - is the role of the monasteries during the Time of Troubles. He concludes that the monasteries were primarily great economic corporations, rather than spiritual institutions, and that their main preoccupation was the pursuit of profit, whichever regime was in power. Only in the later stages of the Troubles, when their profits were threatened, did they participate in initiatives to restore political stability ${ }^{84}$. The third theme of Gruber's book - and the one in which he arguably makes the greatest contribution to our understanding - concerns the role of Orthodox churchmen in developing new concepts of monarchical legitimacy following the dynastic crisis of 1598. In order to justify Boris Godunov's succession, the old hereditary criteria were replaced by three new principles, which Gruber identifies as vox Dei, vox populi and vox feminae. The first of these, the "voice of God", took the form of approval of the new ruler by the Patriarch and other Orthodox hierarchs; the "voice of the people" was expressed by the Assembly of the Land; and the "voice of the woman" was that of Tsaritsa Irina, who sanctioned the transfer of power from her husband, Tsar Fedor, to her brother, Boris Godunov. The "voice of the woman" continued to be heard throughout the Troubles, when the dowager Tsaritsa Maria Nagaia acknowledged the First False Dmitrii as her son, and Marina Mniszech "recognised" the Second Dmitrii as her husband ${ }^{85}$. Finally, as his fourth theme, Gruber argues that Orthodoxy became fragmented during the Time of Troubles, as the Church leadership lost credibility with believers because of its constant shifts of allegiance amongst tsars who were presented as legitimate rulers one day, and as usurpers or impostors the next. The habits of independent thought acquired by the critics of official Orthodoxy during the Troubles, Gruber suggests, may have contributed to the similar independence of thought vis-à-vis the Church hierarchy that was displayed by the Old Believers later in the $17^{\text {th }}$ century ${ }^{86}$.

Gruber's book falls short of the author's aim of providing a comprehensive history of the Church during the Troubles - and indeed, as he himself recognises, the fragmentary nature of the surviving sources makes such an aim a difficult one to achieve ${ }^{87}$. Nevertheless, his account represents an enterprising attempt to deal with a topic which - as the author rightly maintains - has considerable relevance for present-day Russia ${ }^{88}$, and he

\footnotetext{
83 Ibid. P. 23-50, 181-184.

84 Ibid. P. 51-74, 163-172, 184-186.

85 Ibid. P. 75-96, 186-190.

86 Ibid. P. 152-163, 180-181, 190-196.

87 Ibid. P. 18-21.

88 Ibid. P. 11-13, 197.
} 
successfully demythologises some of the more grandiose claims made for the role of the Orthodox Church in saving the country from disaster.

It will be evident from this review that there are no distinct "schools" of Western scholarship on the Time of Troubles: indeed, there are surprisingly few serious studies that deal with the period ${ }^{89}$. The works we have considered are very much the products of individuals who have been attracted to aspects of the Troubles from very different starting points. We can however detect a number of main themes. Samozvantsy have of course been a popular and intriguing subject ever since the $17^{\text {th }}$ century. Philip Barbour makes a lively contribution to the debate about the identity, personality and policies of the First False Dmitrii; and new approaches to cultural history, such as semiotics and the study of mentalités, have led to a reappraisal of the phenomenon of pretendership and the popular attitudes associated with it (Bercé, Perrie). Broader intellectual trends in Western historiography since the Second World War, such as comparative history, have influenced approaches to the social movements of the Time of Troubles (Mousnier, Dunning). Finally, the eternal search for relevance and topicality in relation to present-day concerns has influenced some historians. Paul Avrich found in the Bolotnikov uprising a precedent for the role of peasants and the urban poor in $20^{\text {th }}$ century revolutions; while Isaiah Gruber sees parallels between the $17^{\text {th }}$ century Time of Troubles and Russia's post-Soviet difficulties.

\section{References}

Avrich P. Russian Rebels, 1600-1800. London, Allen Lane The Penguin Press, 1973, 309 p. (first published New York, Schocken Books, 1972).

Barbour P. L. Dimitry, Called the Pretender. Tsar and Great Prince of All Russia, 1605-1606. London, Macmillan, 1967, xxvii + 387 p. (first published - Boston (MA), Houghton Mifflin Publ., 1966).

Bercé Y.-M. Le roi caché. Sauveurs et imposteurs. Mythes politiques populaires dans l'Europe moderne. [Paris], Fayard Publ., 1990, 483 p.

Bercé Y.-M. Révoltes et révolutions dans l'Europe moderne (XVIe - XVIIIe siècles). Paris, Presses Universitaires de France, 1980, 263 p.

Bercé Y.-M. Revolt and Revolution in Early Modern Europe. An Essay on the History of Political Violence. Transl. by Joseph Bergin. Manchester, Manchester University Press, 1987, xii + 236 p.

Berthold-Ignace de Sainte-Anne, Révérend Père. Histoire de l'Établissement de la Mission de Perse par les Pères Carmes-Déchaussées (de l'année1604 à 1612). Brussels, Société Belge de Librairie Publ., 1885, lix $+372 \mathrm{p}$.

Chistov K. V. Russkie narodnye sotsial'no-utopicheskie legendy XVII-XIX vv. Moscow, Nauka Publ., 1967, 341 p. (In Russian).

Crummey R. O. Muscovy and the "General Crisis of the Seventeenth Century". Journal of Early Modern History, vol. 2, 1998, pp. 156-180.

Discussion of H.R. Trevor-Roper: "The General Crisis of the $17^{\text {th }}$ Century". Past and Present, no. 18, November, 1960 , pp. 8-42.

Dunning C.S. L. Russia's First Civil War. The Time of Troubles and the Founding of the Romanov Dynasty. University Park PA, Pennsylvania State University Press, 2001, xiii +657 p.

Florencio del Niño Jesús, P. Fr. A Persia (1604-1609). (Biblioteca Carmelitano-Teresiana de Misiones, t. II). Pamplona, Bengaray Publ., 1929, 158 p.

${ }^{89}$ Perhaps the preoccupation of so many Western historians with the nature of the Russian state has led them to avoid this puzzling period of virtual statelessness. 
Florencio del Niño Jesús, P. Fr. En Persia (1608-1624). (Biblioteca Carmelitano-Teresiana de Misiones, t. III). Pamplona, Bengaray Publ., 1930, 144 p.

Goldstone J. A. Revolution and Rebellion in the Early Modern World. London, University of California Press, 1991, xxix $+608 \mathrm{p}$.

Grey I. Boris Godunov: the Tragic Tsar. London, Hodder and Stoughton, 1973, 188 p.

Gruber I. Orthodox Russia in Crisis: Church and Nation in the Time of Troubles. DeKalb (IL), Northern Illinois University Press, 2012, xi +299 p.

Hobsbawm E. J. The General Crisis of the European Economy in the $17^{\text {th }}$ Century. Past and Present, 1954a, no. 5, May 1, pp. 33-53.

Hobsbawm E. J. The Crisis of the $17^{\text {th }}$ Century - II. Past and Present, 1954b, no. 6, November, pp. 44-65.

Hobsbawm E. J. Primitive Rebels. Studies in Archaic Forms of Social Movement in the $19^{\text {th }}$ and $20^{\text {th }}$ Centuries. Manchester, Manchester University Press, 1959, vii + 208 p.

Hobsbawm E. J. Bandits. Harmondsworth, Penguin Books, 1972, 160 p. (first published -London, Weidenfeld and Nicolson Publ., 1969).

Longworth P. The Pretender Phenomenon in Eighteenth-Century Russia. Past and Present, 1975, no. 66, February, pp. 61-83.

Margeret J. The Russian Empire and Grand Duchy of Muscovy. A $17^{\text {th }}$ Century French Account. Transl. and ed. by Chester S. L. Dunning. Pittsburgh, University of Pittsburgh Press, 1983, xxxvi + 216 p.

Mousnier R. Fureurs paysannes: Les paysans dans les révoltes du XVIIe siècle (France, Russie, Chine). Paris, Calmann-Lévy Publ., 1967, 354 p.

Mousnier R. Peasant Uprisings in $17^{\text {th }}$ Century France, Russia and China. Transl. from the French by Brian Pearce. London, George Allen and Unwin Publ., 1971, xx + 358 p.

Perrie M. Jerome Horsey's Account of the Events of May 1591. Oxford Slavonic Papers. New Series, 1980, vol. XIII, pp. 28-49.

Perrie M. 'Popular Socio-Utopian Legends' in the Time of Troubles. Slavonic and East European Review, 1982, vol. 60, no. 2, April, pp. 221-243.

Perrie M.Pretenders in the Name of the Tsar: Cossack 'Tsareviches' in Seventeenth-Century Russia. Von Moskau nach St. Petersburg. Das russische Reich im 17. Jahrhundert (Forschungen zur osteuropäischen Geschichte, Bd. 56). Hrsg. von Hans-Joachim Torke. Wiesbaden, Harrassowitz Verlag, 2000, Ss. $243-$ 256.

Perrie M. Pretenders and Popular Monarchism in Early Modern Russia: the False Tsars of the Time of Troubles. Cambridge, Cambridge University Press, 1995, xvii +269 p.

Perrie M. 'Royal Marks': Reading the Bodies of Russian Pretenders, $17^{\text {th }}-19^{\text {th }}$ Centuries. Kritika: Explorations in Russian and Eurasian History, New Series, 2010, vol. 11, no.3, Summer, pp. 535-561.

Perri [Perrie] M.Samozvantsy XVII v. i vopros o legitimnosti praviashchego tsaria. Samozvantsy $i$ samozvanchestvo v Moskovii. Materialy mezhdunarodnogo nauchnogo seminara (25 maia $2009 \mathrm{~g}$., Budapesht). Ed. by Diula Svak. Budapest, Russica Pannonicana Publ., 2010, pp. 66-88. (In Russian).

Platonov S. F. Boris Godunov. Petrograd, Ogni Publ., 1921, 157 p. (In Russian).

Platonov S. F. Boris Godunov, Tsar of Russia. Transl. by Rex T. Pyles. With an introductory essay, 'S. F. Platonov: Eminence and Obscurity', by John T. Alexander. Gulf Breeze (FL), Academic International Press, 1973, xlii $+230 \mathrm{p}$.

Platonov S. F. Smutnoe vremia: ocherk istorii vnutrennego krizisa i obshchestvennoi bor'by $v$ Moskovskom gosudarstve XVI i XVII vekov. Peterburg, Vremia Publ., 1923, 166 p. (In Russian).

Platonov S. F. The Time of Troubles: a Historical Study of the Internal Crisis and Social Struggle in $16^{\text {th }}$ - and $17^{\text {th }}$ Century Muscovy. Transl. by John T. Alexander. Lawrence, University Press of Kansas, 1970, $216 \mathrm{p}$.

Rudé G. The Crowd in History. A Study of Popular Disturbances in France and England, 1739-1848. London, Wiley Publ., 1964, ix + 281 p.

Skrynnikov R. G. Boris Godunov. Moscow, Nauka Publ., 1978, 192 p. (In Russian).

Skrynnikov R. G. Boris Godunov. Ed. and transl. by Hugh F. Graham. Gulf Breeze (FL), Academic International Press, 1982, xx $+177 \mathrm{pp}$.

Skrynnikov R. G. Minin i Pozharskii: khronika smutnogo vremeni. Moscow, Molodaia gvardiia Publ., 1981, 328 p. (In Russian).

Skrynnikov R. G. Rossiia v nachale XVII v. "Smuta”. Moscow, Mysl' Publ., 1988b, 283 p. (In Russian).

Skrynnikov R. G. Smuta v Rossii v nachale XVII v. Ivan Bolotnikov. Leningrad, Nauka Publ., 1988c, 256 p. (In Russian).

Skrynnikov R. G. The Civil War in Russia at the Beginning of the Seventeenth Century (1603-1607): its Character and Motive Forces. Transl. by Maureen Perrie. New Perspectives on Muscovite History. Select- 
ed Papers from the Fourth World Congress for Soviet and East European Studies, Harrogate, 1990. Ed. by Lindsey Hughes. Houndmills, Macmillan Publ., 1993, pp. 61-79.

Skrynnikov R. G. The Time of Troubles. Russia in Crisis, 1604-1618. Ed. and transl. by Hugh F. Graham. Gulf Breeze FL, Academic International Press, 1988a, xvi + 337 p.

Smirnov I. I. Vosstanie Bolotnikova 1606-1607. Leningrad, Gosudarstvennoe izdatel'stvo politicheskoi literatury Publ., 1951, 588 p. (In Russian).

Solov'ev S. M. Istoriia Rossii s drevneishikh vremen, kniga IV (t. 7-8). Moscow, Izdatel'stvo sotsial'no-ekonomicheskoi literatury, 1960, 778 p. (In Russian).

Soloviev S. M. The Time of Troubles. Boris Godunov and False Dmitry (History of Russia, vol. 14). Ed. and transl. by G. Edward Orchard. Gulf Breeze (FL), Academic International Press, 1988, xviii + 172 p.

Soloviev S. M. The Time of Troubles. Tsar Vasily Shuisky and the Interregnum, 1606-1613 (History of Russia, vol. 15). Ed., transl. and with an introduction by G. Edward Orchard. Gulf Breeze (FL), Academic International Press, 1989, xxii +377 p.

Stanislavskii A. L. Grazhdanskaia voina v Rossii XVII v. Kazachestvo na perelome istorii. Moscow, Mysl' Publ., 1990, 272 p. (In Russian).

Suvorin A.S. O Dimitrii Samozvantse. Kriticheskie ocherki. St Petersburg, Izdanie A. S. Suvorina, 1906, viii + 223 p. (In Russian).

Trevor-Roper H.R. The General Crisis of the $17^{\text {th }}$ Century. Past and Present, 1959, no. 16, November, pp. 31-64.

Uspenskii B. A. Tsar' i samozvanets: samozvanchestvo v Rossii kak kul'turno-istoricheskii fenomen. Khudozhestvennyi iazyk srednevekov'ia. Moscow, Nauka Publ., 1982, pp. 201-235. (In Russian).

Wolf E. R. Peasant Wars of the Twentieth Century. New York, Harper and Row Publ., 1969. xv + 328 p.

Yaresh L. The 'Peasant Wars' in Soviet Historiography. American Slavic and East European Review, 1957, vol. 16, no. 3, October, pp. 241-259. 